\title{
APMA
}

Jurnal Pengabdian Masyarakat

Volume 1 Nomor 2 Juli 2021

http://jurnal.bhmm.ac.id/index.php/apma/ DOI: 10.47575/apma.v1i2.253

\section{Upaya Peningkatan Derajat Kesehatan Lansia Melalui Pos Pelayanan Terpadu (Posyandu) Lansia}

\author{
* Raudhotun Nisak, Edy Prawoto, Tri Admadi \\ Akademi Keperawatan Pemerintah Kabupaten Ngawi, Indonesia
}

\begin{abstract}
ABSTRAK
Kelompok umur lanjut usia (lansia) merupakan kelompok umur yang rentan dengan berbagai masalah kesehatan akibat munculnya penyakit degeneratif. Lansia membutuhkan pendampingan dalam pencegahan dan penatalaksanaan kesehatannya sehingga perlu dibentuk pos pelayanan terpadu (posyandu) lansia sebagai bentuk kepedulian terhadap lansia. Pengabdian masyarakat ini dilakukan dengan memberikan penyuluhan tentang posyandu lansia dan pelatihan kader posyandu lansia. Kegiatan ini menghasilkan posyandu lansia dengan nama Gatotkaca dan telah membentuk kader posyandu lansia yang sebanyak 5 orang. Posyandu lansia merupakan salah satu wadah kesehatan bagi lansia yang dengan memberdayakan masyarakat setempat guna meningkatkan kesadaran dalam menjaga kesehatan berbasis masyarakat dengan memanfaatkan potensi warga setempat sebagai kader kesehatan posyandu lansia. Posyandu lansia yang telah terbentuk ini, hendaknya dapat dilakukan secara rutin selama sekali dalam sebulan sehingga sehingga dapat senantiasa memfasilitasi kesehatan lansia.
\end{abstract}

Kata kunci : Lansia, Posyandu Lansia.

\begin{abstract}
Elderly is vulnerable group to a range of health problems due to the emergence of degenerative diseases. Elderly need assistance in the prevention and health management so it is necessary to stipulate integrated health care for the elderly as a form of concern to elderly. This activity is carried out by providing information about integrated health care and training for cadres of integrated health care for elderly. This activity produce integrated health care for elderly in the name of Gatotkaca and has established five cadres of integrated health care. It was one container health for elderly who to empower the local community to raise awareness in maintaining health community-based by using local residents potentials as cadres posyandu elderly. This integrated health care for elderly has formed, should be able to be conducted for once in a month so that so that can always facilitate health elderly.
\end{abstract}

Kata kunci : Elderly, Integrated Health Care for Elderly. 


\section{PENDAHULUAN}

Kelompok umur lanjut usia (lansia) merupakan kelompok umur yang rentan setelah usia balita. Dalam rentang usia tersebut, berbagai resiko munculnya penyakit degeneratif seperti hipertensi, penyakit jantung koroner, kanker, diabetes mellitus, osteoporosis, penyakit sendi semakin meningkat. Umumnya, peningkatan beberapa kejadian penyakit ini cenderung meningkat seiring bertambahnya usia sehingga lebih banyak dialami oleh lansia. Proses pertambahan usia sangat berkaitan dengan penurunan fungsi organ tubuh akibat berkurangnya kemampuan sel beregenerasi dan mempertahankan strukturnya (Kholifah, 2016). Hal ini akan menurunkan kualitas hidup lansia sehingga perlu adanya fasilitas pemantauan kesehatan lansia yang dapat meningkatkan dan mempertahankan derajat kesehatan lansia.

Data dari World Population Prospects dan United Nation (UN) menunjukkan Indonesia merupakan negara dengan persentase penduduk lanjut usia paling tinggi $(37,6 \%)$ dibanding negara ASEAN lainnya. Berdasarkan hasil sensus penduduk Indonesia pada tahun 2010, jumlah populasi lanjut usia di Indonesia berkisar 18,04 juta atau 7,6\% dari total populasi di Indonesia. Angka ini akan terus meningkat mencapai 33,7 juta atau 11,8\% pada tahun 2025 dan menjadi 48,2 juta atau $15,8 \%$ pada tahun 2035 . United Nation memprediksikan bahwa persentase penduduk Indonesia berusia di atas 60 tahun akan meningkat menjadi 25\% atau mencapai 74 juta pada tahun 2050 (Adioetomo \& Ghazy Mujahid, 2014). Kementerian Kesehatan Republik Indonesia melalui Riset Kesehatan Dasar (2018) menjelaskan bahwa penyakit yang terbanyak yang dialami lansia khususnya pada penyakit tidak menular antara lain hipertensi, masalah gigi, penyakit sendi, masalah mulut, diabetes mellitus, penyakit jantung dan stroke. Sedangkan pada penyakit menular diantaranya ISPA, diare, dan pneumonia.

Dusun Gajah Desa Ngancar Kecamatan Pitu Kabupaten Ngawi ini memiliki 875 jiwa penduduk dan 99 dari total penduduknya adalah lansia. Berdasarkan data tersebut pula, hanya 90\% lansia memiliki masalah kesehatan seperti hipertensi, radang sendi dan stroke. Informasi yang didapatkan dari Kepada Dusun dan kader kesehatan setempat bahwa Dusun Gajah belum pernah didirikan Posyandu Lansia sebagai sarana masyarakat, khususnya lansia untuk untuk memantau kesehatannya. Beberapa lansia mengatakan jika ada keluhan kesehatan yang muncul maka mereka akan cenderung untuk beristirahat di tempat tidur, mengurangi aktivitas, mengkonsumsi obat-obatan di warung maupun periksa ke puskesmas bagi yang jaraknya terjangkau.

Beberapa masalah kesehatan yang terjadi tersebut apabila dapat terdeteksi secara dini maka tentunya akan mendapatkan pendampingan dan penatalaksanaan yang tepat sehingga dapat dilakukan pencegahan maupun meminimalkan resiko lebih lanjut. Oleh karena itu, untuk mendukung program pemerintah dan sebagai wujud kepedulian terhadap kesehatan lansia maka perlu dibentuk posyandu lansia di Dusun Gajah Desa Ngancar Kecamatan Pitu guna mewujudkan lansia yang sehat, bahagia, berdaya guna dan produktif. 


\section{METODE}

Pengabdian masyarakat dilakukan kepada warga Dusun Gajah, Desa Ngancar, Kecamatan Pitu dengan target sasaran adalah lanjut usia (lansia) sebanyak 99 orang. Rangkaian kegiatan ini dilakukan selama 1 bulan tepatnya pada tanggal 25 Februari-22 Maret 2019. Tahapan kegiatan pengabdian kepada masyarakat ini meliputi perijinan, survei awal, penentuan target populasi, perumusan masalah, perencanaan kegiatan, implementasi kegiatan dan evaluasi kegiatan. Rangkaian kegiatan utama dalam kegiatan ini yaitu penyuluhan dan pembentukan posyandu lansia serta pelatihan kader posyandu lansia. Kegiatan ini dilakukan bersama dengan mahasiswa Akper Pemkab Ngawi sejumlah 6 mahasiswa.

\section{HASIL DAN PEMBAHASAN}

\section{Pembentukan Posyandu Lansia}

Pelaksaanaan kegiatan pembentukan kader kesehatan posyandu lansia dilakukan pada tanggal 26 Februari 2019 pukul 18.30 WIB bertempat di rumah Bapak Kasun. Kegiatan ini dihadiri oleh 98 orang, yang terdiri lansia, tokoh masyarakat dan pihak Puskesmas Pitu sebagai penanggungjawab kesehatan wilayah Desa Ngancar. Sebelum dilakukan pembentukan kader posyandu, undangan yang hadir diberikan pengetahuan terkait tentang pentingnya pengadaan posyandu lansia bagi masyarakat, dimana posyandu lansia tidak hanya diperuntukkan bagi lansia saja tetapi juga dapat memfasilitasi warga yang mempunyai keluhan kesehatan. Seorang individu semakin bertambah usia, maka semakin besar pula kemungkinan dalam mengalami permasalahan, salah satunya permasalahan fisik yang diakibatkan oleh proses degeneratif (Intarti \& Khoriah, 2018). Lansia perlu mendapatkan fasilitas pelayanan kesehatan melalui posyandu lansia yang melibatkan peran masyarakat setempat seperti keluarga, tokoh masyarakat dan organisasi sosial (Setiyawan \& Mardhianti, 2013).

Setelah warga hadir dan menyatakan kesediaannya, maka dibentuklah posyandu lansia. Adapun nama posyandu lansia yang dipilih adalah posyandu lansia Gathotkaca yang pada kegiatan ini diresmikan bersama-sama oleh Kepala Puskesmas Pitu dan Akper Pemkab Ngawi. Selanjutnya, warga dipersilakan untuk memilih kader kesehatan posyandu lansia dan terpilihlah 5 (lima) kader kesehatan yang akan bertugas dalam mengkoordinasikan pelaksanaan posyandu lansia. Adapun struktur kader kesehatan yang akan bertanggungjawab pada pelaksanaan posyandu lansia yaitu Ketua (Ibu Cicik Yulia), Wakil Ketua (Ibu Endang), Sekretaris (Ibu Sri Wahyuni dan Ibu Wasis), dan Bendahara : Ibu Rusmini. Semua kader yang dipilih tersebut sesuai dengan kesepakatan warga karena dianggap layak untuk dijadikan sebagai kader. Sebagaimana Setiyawan \& Mardhianti, (2013) bahwa kriteria pemilihan kader posyandu yaitu mampu membaca dan menulis, memiliki jiwa sosial, tinggal di wilayah posyandu sehingga dapat mengetahui adat istiadat setempat, ramah dan dapat diterima oleh masyarakat. 
APMA : Jurnal Pengabdian Masyarakat Raudhotun Nisak dkk., Upaya Peningkatan Derajat Volume 1 Nomor 2 Juli 2021 Kesehatan Lansia

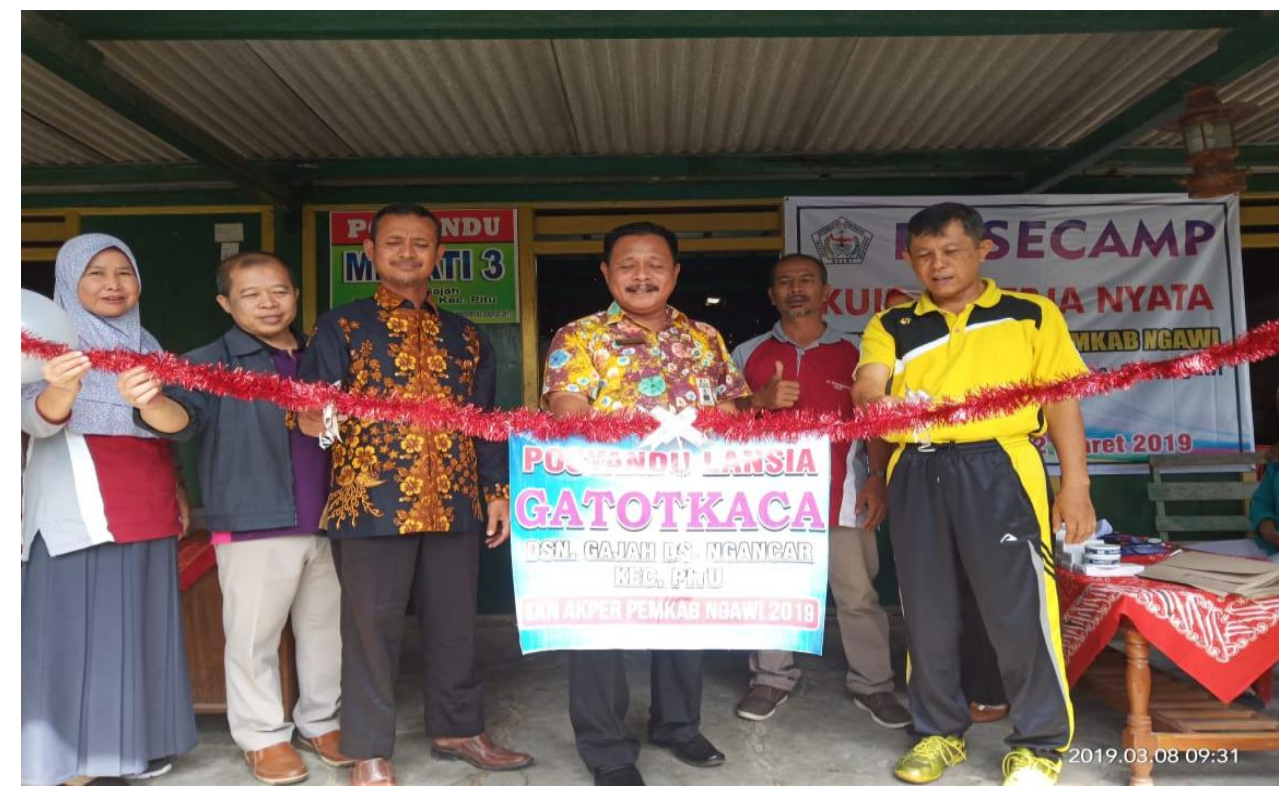

Gambar 1

Peresmian Pembentukan Posyandu Gatotkaca

Kegiatan pelatihan kader lansia dilakukan pada tanggal 28 Februari di rumah Ibu Cicik Yulia pada pukul 16.00 WIB. Pelatihan kader ini meliputi tentang cara pengukuran tekanan darah dan kegiatan pelaksanaan posyandu lansia yang meliputi 5 meja. Kader kesehatan diberi pengetahuan tentang 5 meja yang harus ada pada kegiatan posyandu lansia. Pelayanan posyandu lansia dapat dilakukan dengan model 5 meja, yang meliputi meja 1 (pendaftaran), meja 2 (pengukuran dan penimbangan berat badan), meja 3 (pencatatan dan pengisian KMS), meja 4 (penyuluhan, dan pemberian PMT) dan meja 5 (pemeriksaan kesehatan dan pengobatan) (Ismawati, 2010).

\section{Kegiatan Pelatihan Kader Lansia}

Kegiatan pelatihan kader lansia dilakukan pada tanggal 28 Februari di rumah Ibu Cicik Yulia pada pukul 16.00 WIB. Pelatihan kader ini meliputi tentang cara pengukuran tekanan darah dan kegiatan pelaksanaan posyandu lansia yang meliputi 5 meja. Kader kesehatan diberi pengetahuan tentang 5 meja yang harus ada pada kegiatan posyandu lansia. Pelayanan posyandu lansia dapat dilakukan dengan model 5 meja, yang meliputi meja 1 (pendaftaran), meja 2 (pengukuran dan penimbangan berat badan), meja 3 (pencatatan dan pengisian KMS), meja 4 (penyuluhan, dan pemberian PMT) dan meja 5 (pemeriksaan kesehatan dan pengobatan) (Ismawati, 2010). 


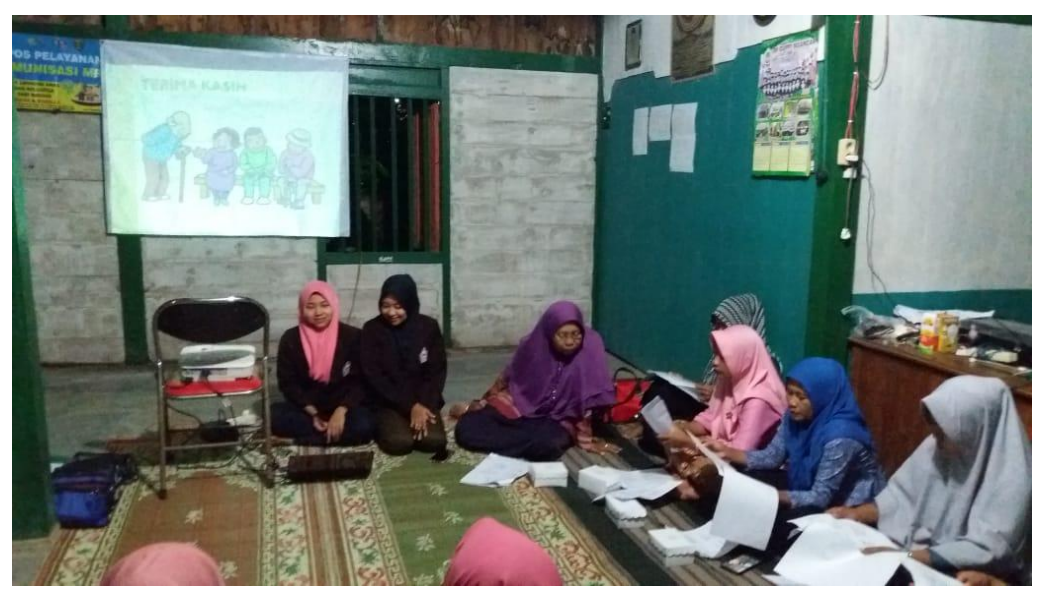

Gambar 2

Pelatihan Kader

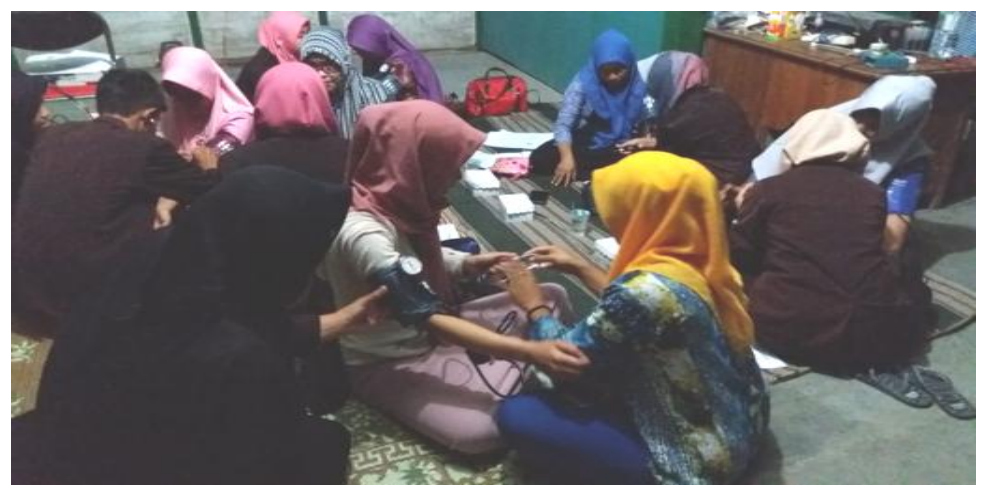

Gambar 3

Pelatihan Pengukuran Tekanan Darah

Pada kegiatan pelatihan pengukuran tekanan darah diawali dengan brainstorming untuk melihat sejauh mana kader telah mengetahui pentingnya tekanan darah pada kesehatan seseorang. Pelatihan dilakukan dengan metode ceramah, diskusi, praktik dan simulasi. Selanjutnya kader diajarkan menggunakan tekanan darah dan intepretasi hasilnya. Kader juga diberikan simulasi untuk mencoba melakukan pengukuran tekanan darah pada sesama rekan kader dan menuliskan di buku catatan. Notoatmodjo dalam Rachmawati (2019) menyebutkan bahwa pelatihan dengan metode ceramah yang disertai diskusi, simulasi, dan praktik dapat meningkatkan pengetahuan. Oleh karena itu, diharapkan dengan pelatihan pengukuran tekanan darah ini, kader juga memiliki peran dalam membantu mendeteksi penyakit hipertensi yang seringn dialami oleh lansia. Selama kegiatan berlangsung, kader menunjukkan antusiasme dalam mengikuti pelatihan dan kemampuan dalam mempraktikkan kembali cara pemeriksaan tekanan darah. Setelah dilakukan pelatihan pengukuran tekanan darah diharapkan kader kesehatan mampu termotivasi untuk mempertahankan serta meningkatkan kemampuan keterampilan tersebut. 


\section{SIMPULAN}

Posyandu lansia merupakan salah satu wadah kesehatan bagi lansia yang sangat bermanfaat bagi lansia khususnya. Kegiatan ini selayaknya harus ada di setiap dusun pedesaan karena keberadaannya dapat memfasilitasi lansia untuk mendeteksi secara dini gangguan kesehatan yang muncul seiring dengan bertambahnya usia mereka. Kegiatan ini juga juga bermanfaat guna memberdayakan masyarakat setempat guna meningkatkan kesadaran dalam menjaga kesehatan berbasis masyarakat dengan memanfaatkan potensi warga setempat sebagai kader kesehatan posyandu lansia. Posyandu lansia yang telah terbentuk ini, hendaknya dapat dilakukan secara rutin sebulan sekali sehingga sehingga dapat senantiasa memfasilitasi kesehatan lansia. Selain itu juga perlu adanya dukungan yang optimal dari puskemas setempat untuk keberlangsungan posyandu lansia.

\section{UCAPAN TERIMA KASIH}

Ucapan terimakasih disampaikan kepada Kepala Desa Ngancar, kepala dusun Dusun Gajah, ibu-ibu kader dan warga Desa Gajah Wilayah Puskesmas Pitu yang telah membantu kegiatan terlaksananya program pengabdian masyarakat.

\section{DAFTAR PUSTAKA}

Adioetomo, S. M., \& Ghazy Mujahid. (2014). Indonesia on the Threshold of Population Ageing (Issue 1). UNFPA Indonesia. https://doi.org/10.1299/kikaic.65.1319

Intarti, W. D., \& Khoriah, S. N. (2018). Faktor-Faktor yang Mempengaruhi Pemanfaatan Posyandu Lansia. JHeS (Journal of Health Studies), 2(1), 110122. https://doi.org/10.31101/jhes.439

Ismawati, C. (2010). Posyandu dan Desa Siaga: Panduan Untuk Bidan dan Kader. Nuha Medika.

Kementerian Kesehatan Republik Indonesia. (2018). Hasil Utama Riskesdas 2018.

Kholifah, S. N. (2016). Keperawata Gerontik. Kementerian Kesehatan RI.

Rachmawati, W. C. (2019). Promosi Kesehatan dan Ilmu Perilaku. Wineka Media.

Setiyawan, A., \& Mardhianti, R. (2013). Kinerja Kader Posyandu Sebagai Faktor Pendukung Terbentuknya Tingkat Kemandirian Posyandu. Jurnal Ilmiah Kesehatan, 2(3). https://doi.org/10.35952/jik.v2i3.70. 